\title{
Systemic Lupus Erythematosus and Pregnancy: A Single-Center Observational Study of 69 Pregnancies
}

\section{Lúpus eritematoso sistêmico e gravidez: estudo observacional em um único centro com 69 gestações}

\author{
Estephania Pignaton Naseri ${ }^{1}$ Fernanda Garanhani Surita ${ }^{2}$ Anderson Borovac-Pinheiro ${ }^{2}$ \\ Marília Santos ${ }^{1}$ Simone Appenzeller ${ }^{1}$ Lilian Tereza Lavras Costallat ${ }^{1}$ \\ ${ }^{1}$ Department of Internal Medicine, Universidade Estadual de \\ Campinas, Campinas, São Paulo, Brazil \\ 2 Department of Obstetrics and Gynecology, Universidade Estadual de \\ Campinas, Campinas, São Paulo, Brazil \\ Address for correspondence Fernanda Garanhani Surita, MD, PhD, \\ Departamento de Obstetrícia e Ginecologia, Universidade Estadual de \\ Campinas, Rua Alexander Fleming, 101, 13083-881, Campinas, SP, \\ Brazil (e-mail: surita@unicamp.br).
}

Rev Bras Ginecol Obstet 2018;40:587-592.

\section{Abstract \\ Keywords \\ - systemic lupus erythematosus \\ - pregnancy \\ - obstetric complications \\ - perinatal death}

Resumo
Objective To evaluate the effects of pregnancy in systemic lupus erythematosus (SLE) patients.

Methods The present article is a retrospective cohort study. Data were collected from medical records of pregnant women with SLE from January 2002 to December 2012 at Universidade Estadual de Campinas, in the city of Campinas, state of São Paulo, Brazil. Systemic lupus erythematosus and disease activity were defined according to the American College of Rheumatology and the Systemic Lupus Erythematosus Disease Activity Index (SLEDAI) criteria respectively. The means, standard deviations (SDs), percentages and correlations were performed using the SAS software, version 9.4 (SAS Institute Inc., Cary, NC, US).

Results We obtained data from 69 pregnancies in 58 women. During pregnancy, a new flare was observed in $39.2 \%(n=27)$. The manifestations were most common in patients with prior kidney disease, and mainly occurred during the third quarter and the puerperium. Renal activity occurred in $24.6 \%(n=17)$, and serious activity, in $16 \%$ ( $n=11)$. Of all deliveries, $75 \%(n=48)$ were by cesarean section. Two maternal deaths occurred (3\%). Preterm birth was the main complication in the newborns. The abortion rate was $8.7 \%$. Severe SLEDAI during pregnancy was associated with prematurity (100\%) and perinatal death (54\%).

Conclusion The maternal-fetal outcome is worse in SLE when the women experience a flare during pregnancy. The best maternal-fetal outcomes occur when the disease is in remission for at least 6 months before the pregnancy.

Objetivo Avaliar os efeitos da gravidez em pacientes com lúpus eritematoso sistêmico (LES).

Métodos Estudo de coorte retrospectivo. Os dados foram coletados de prontuários de mulheres com LES que engravidaram de janeiro de 2002 a dezembro de 2012 na received

May 9, 2018

accepted

June 27, 2018
DOI https://doi.org/

10.1055/s-0038-1672136. ISSN 0100-7203.
Copyright $\odot 2018$ by Thieme Revinter Publicações Ltda, Rio de Janeiro, Brazil
License terms

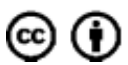




\begin{tabular}{|c|c|}
\hline $\begin{array}{l}\text { Descritores } \\
\text { - lúpus eritematoso } \\
\text { sistêmico } \\
\text { - gravidez } \\
\text { - complicações } \\
\text { obstétricas } \\
\text { - } \text { morte perinatal }\end{array}$ & $\begin{array}{l}\text { Universidade Estadual de Campinas, São Paulo, Brasil. Lúpus eritematoso sistêmico e } \\
\text { atividade da doença foram definidos segundo o American College of Rheumatology e os } \\
\text { critérios do Índice de Atividade da Doença de Lúpus Eritematoso (SLEDAl, na sigla em inglês), } \\
\text { respectivamente. As médias, os desvios-padrão (DP), as porcentagens e as correlações } \\
\text { foram realizados utilizando o software SAS, versão } 9.4 \text { (SAS Institute Inc., Cary, NC, US). } \\
\text { Resultados Obtivemos dados de } 69 \text { gestações em } 58 \text { mulheres. Durante a gravidez, a } \\
\text { reatividade da doença foi observada em } 39.2 \%(n=27 \text { ). As manifestações mais } \\
\text { comuns foram em pacientes com doença renal prévia, e ocorreram principalmente } \\
\text { no terceiro trimestre e no puerpério. Atividade renal ocorreu em } 24,6 \% \text { ( } n=17 \text { ), e } \\
\text { atividade grave, em } 16 \% \text { ( } n=11 \text { ). De todos os partos, } 75 \% \text { ( } n=48 \text { ) foram por } \\
\text { cesariana. Dois óbitos maternos ocorreram ( } 3 \%) \text {. A prematuridade foi a principal } \\
\text { complicação nos recém-nascidos. A taxa de aborto foi de } 8,7 \% \text {. O índice SLEDAl grave } \\
\text { durante a gestação foi associado à prematuridade ( } 100 \% \text { ) e à morte perinatal (54\%). } \\
\text { Conclusão O resultado materno-fetal é pior no LES quando as mulheres sofrem crise } \\
\text { de reativação durante a gravidez. Os melhores desfechos materno-fetais ocorrem } \\
\text { quando a doença está em remissão por pelo menos } 6 \text { meses anteriores à gestação. }\end{array}$ \\
\hline
\end{tabular}

\section{Introduction}

Systemic lupus erythematosus (SLE) is a chronic multisystem autoimmune disease that mainly affects women of childbearing age. However, their fertility, regardless of the severity of the disease, is preserved. ${ }^{1,2}$

In patients with rheumatic autoimmune diseases, particularly SLE, pregnancy presents a challenge for the physicians. Pregnant women with lupus have a higher mortality risk and a greater risk of eclampsia, preeclampsia, preterm birth, and thromboembolic events, in addition to an increase in the disease activity itself. In pregnant SLE patients, complications associated with the disease are often difficult to distinguish from physiological changes or complications arising from the pregnancy itself. ${ }^{2,3}$

The association of SLE and antiphospholipid antibodies and antiphospholipid antibody syndrome (APS) further increases the probability of miscarriage, restricted intrauterine growth, mortality, and perinatal complications. ${ }^{4}$ These antibodies are present in $\sim 25-50 \%$ of all SLE patients, but only a small proportion of patients with antiphospholipid antibodies develop APS. ${ }^{4,5}$ The presence of the anticoagulant isolated antibody is more helpful for predicting the risk of a negative outcome in such cases. ${ }^{5}$ Three decades ago, female SLE patients would simply be discouraged from getting pregnant. However, several studies, particularly those evaluating the use of antimalarial drugs during pregnancy, have shown favorable maternal-fetal outcomes in cases of SLE. For successful outcomes, the participation of a multidisciplinary team involving rheumatologists, obstetricians, and pediatricians is required, although this is not feasible in developing countries. ${ }^{1,6,7}$

In the present study, we evaluated SLE patients whose prenatal care was administered by a team of experts in rheumatology and high-risk obstetrics of Hospital de Clínicas da Universidade Estadual de Campinas (HC/Unicamp), in the Portuguese acronym), in the city of Campinas, state of São Paulo, Brazil, to evaluate complications and outcomes in these patients.

\section{Methods}

A retrospective cohort study was conducted at HC/Unicamp, which is a reference hospital center that covers an area with $\sim 4$ million inhabitants. It performs $\sim 2,800$ high-risk deliveries each year, and has an assistance protocol specifically designed for the care of pregnant women with SLE.

We included 58 women with SLE followed in the outpatient clinic of Rheumatology who became pregnant, totaling 69 pregnancies from January 2002 to December 2012. During the pregnancy and childbirth, these patients were followed in high-risk prenatal care at Centro de Atenção Integral à Saúde da Mulher (CAISM, in the Portuguese acronym), a center specialized in the care of female patients that is part of the HC/Unicamp.

All women were $>18$ years old and met the classification criteria of the American College of Rheumatology (1997). ${ }^{8}$ We observed the newborns from birth until they were discharged from the hospital.

We have collected data from medical records using a data collection form, and disease activity was defined through the Systemic Lupus Disease Activity Index (SLEDAI. The calculation of the SLEDAI was made with data from 6 months prior to the beginning of the pregnancy and every time the patients showed changes in clinical and laboratory findings during pregnancy. Disease activity was considered mild to moderate when the SLEDAI was $>4$ and severe when it was $>12 .^{9}$

Data were incorporated in a Microsoft Excel (Microsoft Corporation, Redmond, WA, US) worksheet, and the statistical analysis was performed using the SAS software (SAS Institute Inc., Cary, NC, US), version 9.4, for Windows. Values of $p<0.05$ were considered statistically significant.

The exploratory data analysis was developed by assessing frequency, percentages, averages, and standard deviation (SD). We used the Fisher exact test to establish correlations among variables. 
The institutional review board assessed and approved the research protocol before data collection started (approval number 30310114.2.0000.5404).

\section{Results}

We have obtained data from 69 pregnancies in 58 women: 16 (23\%) had planned the pregnancy; however, all $100 \%$ of the pregnancies were desired. The average age was 33 years old $(\mathrm{SD} \pm 7)$ at the time of delivery, and $76 \%(n=53)$ of the sample was aged between 31 and 45 years. Of all patients, $65 \%(n=45)$ received prenatal counseling. The average age was 23 years old $(\mathrm{SD} \pm 5.8)$ at the time of SLE diagnosis, with an average duration of the disease of 4.45 years ( $S D \pm 4.83$ ). Systemic lupus erythematosus was diagnosed during pregnancy in 4 patients (5.8\%). A prior abortion had occurred in $4 \%(n=12)$, stillbirth, in $7.3 \%(n=5), 34 \%(n=24)$ were nulliparous, and $\sim$ $45 \%(n=31)$ of the patients already had living children before the diagnosis. - Table 1 shows SLE manifestations and drugs used before pregnancy. Upon the diagnosis of pregnancy, $20 \%$ of all patients ceased using immunosuppressant drugs, either by themselves or as per the suggestion of the diagnosing physician.

Previous comorbidities, such as hypertension and diabetes, were present in 16 of 58 - 23\% of all women; 12 (17.4\%) women presented with associated APS, and $18(26.1 \%)$ presented with

Table 1 SLE Manifestations and drugs used before pregnancy

\begin{tabular}{|l|l|}
\hline & $\mathbf{n}(\%)$ \\
\hline Activity signs & \\
\hline Antinuclear antibody & $68(98.6)$ \\
\hline Arthritis & $56(81.2)$ \\
\hline Immunologic change & $50(72.4)$ \\
\hline Anti-antibody DNA & $34(42.2)$ \\
\hline Photosensitivity & $48(69.6)$ \\
\hline Hematologic change & $37(53.6)$ \\
\hline Malar rash & $35(50.7)$ \\
\hline Serositis & $18(26.0)$ \\
\hline Renal involvement & $18(26.0)$ \\
\hline Discoid lupus & $9(13.0)$ \\
\hline Neurological involvement & $8(11.5)$ \\
\hline Oral ulcers & $6(8.7)$ \\
\hline Drugs used & $63(91.3)$ \\
\hline Prednisone $\leq 20 \mathrm{mg} /$ day & $49(71.0)$ \\
\hline Hydroxychloroquine & $23(33.3)$ \\
\hline Azathioprine & $15(21.7)$ \\
\hline Chloroquine diphosphate & $7(10.1)$ \\
\hline Prednisone $\geq 0.5 \mathrm{mg} / \mathrm{Kg} /$ day & $6(8.7)$ \\
\hline Cyclophosphamide & $3(4.2)$ \\
\hline Biological (abatacept) & $1(1.5)$ \\
\hline Mycophenolate & $1(1.5)$ \\
\hline
\end{tabular}

1 or more antiphospholipid antibodies with no clinical diagnosis of APS.

During pregnancy, a new flare (disease activity) was observed in 27 (39.2\%) women, particularly during the 2nd and 3rd trimesters. Renal activity occurred in $24.6 \%(n=17)$, and serious activity, in $16 \%(n=11)$ of the women. Renal involvement is related with flare presentation (66\%), with worsened renal function found in $41 \%$ of the cases after the flare. The activity of SLE during pregnancy and the fetal outcomes are shown in -Table 2.

Table 2 Systemic lupus erythematosus activity during pregnancy and perinatal outcomes

\begin{tabular}{|c|c|}
\hline & N (\%) \\
\hline Disease reactivation during pregnancy & $27(39.2)$ \\
\hline 1st quarter & $3(4.4)$ \\
\hline 2st quarter & $8(11.6)$ \\
\hline 3st quarter & $16(23.2)$ \\
\hline Disease reactivation during the puerperium & $7(10.1)$ \\
\hline Arthritis & $9(16.3)$ \\
\hline Cutaneous & $16(29.0)$ \\
\hline Hematological & $14(25.4)$ \\
\hline Autoimmune hemolytic anemia & $3(5.4)$ \\
\hline Thrombocytopenia & $4(7.2)$ \\
\hline Leukopenia & $7(12.7)$ \\
\hline Serositis & $1(1.8)$ \\
\hline Renal Injury & $14(25.4)$ \\
\hline Central nervous system vasculitis & $1(1.8)$ \\
\hline Anti-antibody DNA & $7(10.1)$ \\
\hline Complement consumption & $27(39.2)$ \\
\hline \multicolumn{2}{|l|}{$\begin{array}{l}\text { Systemic Lupus Erythematosus } \\
\text { Disease Activity Index* }\end{array}$} \\
\hline Activity & $19(27.9)$ \\
\hline Severe activity & $11(16.2)$ \\
\hline No activity & $38(55.9)$ \\
\hline Fetal death & $11(15.9)$ \\
\hline Abortion & $5(7.3)$ \\
\hline up to 6 & $2(4.6)$ \\
\hline$\geq 7$ & $42(95.5)$ \\
\hline Preterm birth ${ }^{* * *}$ & $37(59.4)$ \\
\hline$<28$ weeks & 7 (10.9) \\
\hline 28-34 weeks & $13(20.3)$ \\
\hline $34-<37$ weeks & $17(26.6)$ \\
\hline Intensive care unit admission ${ }^{* * * *}$ & $7(11.7)$ \\
\hline \multicolumn{2}{|l|}{ Weight at birth ${ }^{* * * *}$} \\
\hline Small for gestational age & $11(18.3)$ \\
\hline Adequate for gestational age & $49(81.7)$ \\
\hline Large for gestational age & $0(0.0)$ \\
\hline Birth defects & $3(4.3)$ \\
\hline
\end{tabular}

Notes: Missing: ${ }^{*} 1,{ }^{* *} 25,{ }^{* * *} 5,{ }^{* * * *} 9$. 
Table 3 Perinatal outcomes according to pregestational and gestational activity of Systemic Lupus Erythematosus

\begin{tabular}{|l|l|l|l|l|l|l|l|l|}
\hline & \multicolumn{3}{|l}{ PREGESTATIONAL SLEDAI } & \multicolumn{2}{l|}{ GESTATIONAL SLEDAI } \\
\hline & No activity & Activity & $\begin{array}{l}\text { Severe } \\
\text { activity }\end{array}$ & $\mathbf{p}$-value & No activity & Activity & $\begin{array}{l}\text { Severe } \\
\text { activity }\end{array}$ & -value \\
\hline & $\mathbf{n}(\%)$ & $\mathbf{n}(\%)$ & $\mathbf{n}(\%)$ & & $\mathbf{n}(\%)$ & $\mathbf{n}(\%)$ & $\mathbf{n}(\%)$ & \\
\hline Mode of delivery* & & & & 1.00 & & & & 0.37 \\
\hline C-section & $35(74.5)$ & $9(75.0)$ & $4(80.0)$ & & $28(80.0)$ & $13(72.2)$ & $6(60.0)$ & \\
\hline Vaginal & $12(25.5)$ & $3(25.0)$ & $1(20.0)$ & & $7(20.0)$ & $5(27.8)$ & $4(40.0)$ & \\
\hline Prematurity* & & & & 0.05 & & & & 0.01 \\
\hline No & $23(48.9)$ & $3(25.0)$ & $0(0.0)$ & & $18(51.4)$ & $8(44.4)$ & $0(0.0)$ & \\
\hline Yes & $24(51.1)$ & $9(75.0)$ & $5(100.0)$ & & $17(48.6)$ & $10(55.6)$ & $10(100.0)$ & \\
\hline Apgar 5** & & & & 0.70 & & & & 0.43 \\
\hline Up to 6 & $5(14.7)$ & $0(0.0)$ & $0(0.0)$ & & $5(16.7)$ & $0(0.0)$ & $0(0.0)$ & \\
\hline$\geq 7$ & $29(85.3)$ & $7(100.0)$ & $5(100.0)$ & & $25(83.3)$ & $10(100.0)$ & $4(100.0)$ & \\
\hline Perinatal death & & & & 0.07 & & & & $<0.01$ \\
\hline No & $44(88.0)$ & $1(84.6)$ & $3(50.0)$ & & $38(100.0)$ & $15(78.9)$ & $5(45.5)$ & \\
\hline Yes & $6(12.0)$ & $2(15.4)$ & $3(50.0)$ & & $0(0.0)$ & $4(21.1)$ & $6(54.5)$ & \\
\hline
\end{tabular}

Abbreviations: C-section, cesarean section; SLEDAI, Systemic Lupus Erythematosus Disease Activity Index.

Notes: missing: ${ }^{*}{ }^{* *} 25$.

Of all deliveries, $75 \%(n=48)$ were by cesarean section. Regarding pregnancy-associated complications, gestational diabetes was diagnosed in $2.9 \%(n=2)$, pre-eclampsia in $10 \%$ $(n=7), 2$ women $(2.9 \%)$ had sepsis, and there were no cases of eclampsia or HELLP syndrome (hemolysis, elevated liver enzyme levels, and low platelet levels). Two (3\%) maternal deaths occurred ( - Table 3 ).

After the delivery, almost all women (98\%) received contraceptive guidelines and $62 \%$ immediately started a new contraceptive method, while 35\% (20) opted for tubal ligation.

Birth defects were observed in 3 newborns, 1 of them with tetralogy of Fallot. In this case, the mother had lupus nephritis, and was being treated with intravenous cyclophosphamide. The other observed malformations were megaureter $(n=1)$ and hydronephrosis $(n=1)$. These two cases occurred in women without disease activity for six months prior to the pregnancy. Only one case of neonatal SLE was described, which presented with skin and hematological changes, without cardiac alterations.

\section{Discussion}

The present study aimed to evaluate the effects of SLE previously and during pregnancy. The data showed that cutaneous and hematologic activities were the most common presentations previously and during pregnancy, and that almost all women were using prescription drugs during the conception period.

In our sample, 27 (39.2\%) of the patients experienced a flare during pregnancy, an expected percentage according to previous studies (13-65\%). ${ }^{10}$ In a previous study conducted at the same center and involving 76 pregnancies, flares occurred in $85 \%$ of the cases. ${ }^{11}$ We attribute this improve- ment to increased use of hydroxychloroquine by pregnant women in recent years, and to the lower renal involvement before the pregnancy presented by the patients in the study (26\% in the present study versus $66 \%$ in the previous study). In patients with renal involvement prior to the pregnancy, $66 \%$ presented with a flare, and subsequent worsening of renal function was observed in $41 \%$ of the cases. These data are in line with previous studies showing that patients with SLE with and without prior nephritis presented a risk of flare of $54.2 \%$ versus $25 \%$ ( $p=0.04$ ), and exclusively renal flare in $45.7 \%$ versus $6.6 \%(p=0.0001) .^{12,13}$ The majority of the disease activity observed in these patients ranged from mild to moderate, with new cutaneous-articular changes. The episodes of disease activity were mainly observed in the second and third trimesters.

Chen et $\mathrm{al}^{14}$ described 83 pregnancies of patients with SLE that were divided into 3 groups: patients in remission for more than 6 months, patients with disease activity in the previous 6 months, and patients who were diagnosed with SLE during pregnancy. In this study, the SLEDAI calculated six months prior to the pregnancy period was significantly associated with flare and fetal loss. ${ }^{14}$ In the present study, the SLEDAI evaluated at the moment the flare occurred had a significant association with perinatal death $(p<0.01)$; $50 \%$ of perinatal deaths occurred in those with severe disease activity, as shown by the SLEDAI, while $21 \%$ of the fetal deaths occurred in those with mild to moderate disease activity, and no fetal deaths occurred in patients without flare.

Systemic lupus erythematosus was diagnosed during pregnancy in four patients with severe disease activity and with severe maternal or maternal-fetal outcome. Fetal death occurred in three of them, and two patients died. 
One woman died during the 12th week of pregnancy; this patient had had a previous miscarriage. This woman presented with severe thrombocytopenia and serositis. The other maternal death occurred during the 33rd week of pregnancy in a women with a high SLEDAI $<6$ months prior to the pregnancy and an active lupus nephritis with worsened renal function during the pregnancy. Both died due to pulmonary sepsis shock secondary to a pulse of methylprednisolone. The main reason for maternal death in women with SLE found in the literature is pulmonary infection involved with sepsis. $^{15,16}$

The maternal death rate in our study is in line with the literature (3\%). ${ }^{15}$ The main cause of maternal death is sepsis (40\%), followed by disease activity (30\%), and secondary causes include pulmonary embolism, cardiomyopathy, and kidney failure, which were less frequent. ${ }^{15,16}$

Diabetes and hypertension were found as severe complications related with pregnant women with SLE . Nevertheless, although the cohort previously used corticosteroids, diabetes diagnosed during pregnancy was only observed in two cases, with no newborns large for gestational age. Preeclampsia was found in 7 (10\%) women, and no difference was observed among women with flare and without flare during pregnancy. According to previous studies, the risk of preeclampsia in SLE patients ranges from 10 to $35 \%$, which is similar to what was observed in the present study, although the risk of preeclampsia is particularly high in patients who have chronic kidney disease. ${ }^{13,17}$

As expected, premature birth was the main complication observed in the newborns. Of all newborns, 37 (59\%) were born prematurely, with extreme premature birth $(<28$ weeks) in 7 of $69(10 \%)$ of the cases. In previous studies, $\sim 40 \%$ of all newborns were born prematurely. ${ }^{15}$ High disease activity was the main predictor of preterm birth in women with SLE. ${ }^{18}$

Neonatal lupus was diagnosed only in one case in which the mother did not experience a flare during pregnancy, but had Anti-Ro and Anti-La antibodies. The fetus developed properly during the gestation, and was born at term, with an appearance, pulse, grimace, activity, and respiration (APGAR) score of 9 and 10 at 5 and 10 minutes of life respectively, showing only cutaneous manifestations and lymphopenia, without any cardiac change. Two studies show neonatal cutaneous involvement present in around $37 \%$ of all cases of neonatal lupus. ${ }^{19,20}$ The prevalence of neonatal hematological changes is uncertain. ${ }^{20}$

\section{Conclusion}

The present study assessed pregnancy in women with SLE and evaluated previous manifestations and perinatal outcomes. However, it has some limitations: data collection had no control, and we had some data loss because it was a retrospective study. Nevertheless, the study shows the improvement in the pattern of the outcome in pregnant women with SLE, especially after the introduction of hydroxychloroquine, when compared with data already existing in the literature. Pregnancy in women with SLE is considered of high risk, and that risk is even higher in unplanned pregnancies with high disease activity and when the disease is diagnosed during pregnancy. On these occasions, even with expert multidisciplinary follow-up, there is a great risk of premature birth and perinatal death.

\section{Contributors}

The idea for the present study and this specific analysis was conceived by Naseri EP, Surita FG, and Costallat LTL. Data collection by Naseri EP and Santos M. All authors were involved in data analysis and interpretation. Naseri EP, Borovac-Pinheiro A and Surita FG wrote the paper. All authors were responsible for the final content.

Conflict of Interests

The authors have no conflict of interests to declare.

\section{References}

1 Lateef A, Petri M. Systemic lupus erythematosus and pregnancy. Rheum Dis Clin North Am 2017;43(02):215-226. Doi: 10.1016/j. rdc.2016.12.009

2 Saavedra Salinas MA, Barrera Cruz A, Cabral Castañeda AR, et al. Guías de práctica clínica para la atención del embarazo en mujeres con enfermedades reumáticas autoinmunes del Colegio Mexicano de Reumatología. Parte I. Reumatol Clin 2015;11(05): 295-304. Doi: 10.1016/j.reuma.2014.11.005

3 Yamamoto Y, Aoki S. Systemic lupus erythematosus: strategies to improve pregnancy outcomes. Int J Womens Health 2016; 8:265-272. Doi: 10.2147/IJWH.S90157

4 Schreiber K, Breen K, Cohen H, et al. HYdroxychloroquine to Improve Pregnancy Outcome in Women with AnTIphospholipid Antibodies (HYPATIA) protocol: a multinational randomized controlled trial of hydroxychloroquine versus placebo in addition to standard treatment in pregnant women with antiphospholipid syndrome or antibodies. Semin Thromb Hemost 2017;43(06): 562-571. Doi: 10.1055/s-0037-1603359

5 Jara LJ, Medina G, Cruz-Dominguez P, Navarro C, Vera-Lastra O, Saavedra MA. Risk factors of systemic lupus erythematosus flares during pregnancy. Immunol Res 2014;60(2-3):184-192. Doi: 10.1007/s12026-014-8577-1

6 Baer AN, Witter FR, Petri M. Lupus and pregnancy. Obstet Gynecol Surv 2011;66(10):639-653. Doi: 10.1097/OGX.0b013e318239e1ee

7 Knight CL, Nelson-Piercy C. Management of systemic lupus erythematosus during pregnancy: challenges and solutions. Open Access Rheumatol 2017;9:37-53. Doi: 10.2147/OARRR.S87828

8 Hochberg MC. Updating the American College of Rheumatology revised criteria for the classification of systemic lupus erythematosus. Arthritis Rheum 1997;40(09):1725. Doi: 10.1002/15290131(199709)40:9\&lt;1725:AID-ART29\&gt;3.0.CO;2-Y

9 Bombardier C, Gladman DD, Urowitz MB, Caron D, Chang CH; The Committee on Prognosis Studies in SLE. Derivation of the SLEDAI. A disease activity index for lupus patients. Arthritis Rheum 1992; 35(06):630-640. Doi: 10.1002/art.1780350606

10 Borella E, Lojacono A, Gatto M, et al. Predictors of maternal and fetal complications in SLE patients: a prospective study. Immunol Res 2014;60(2-3):170-176. Doi: 10.1007/s12026-014-8572-6

11 Surita FG, Parpinelli MA, Yonehara E, Krupa F, Cecatti JG. Systemic lupus erythematosus and pregnancy: clinical evolution, maternal and perinatal outcomes and placental findings. Sao Paulo Med J 2007;125(02):91-95. Doi: 10.1590/S1516-31802007000200005

12 Kwok LW, Tam LS, Zhu T, Leung YY, Li E. Predictors of maternal and fetal outcomes in pregnancies of patients with systemic lupus erythematosus. Lupus 2011;20(08):829-836. Doi: 10.1177/096120 3310397967

13 Kattah AG, Garovic VD. Pregnancy and lupus nephritis. Semin Nephrol 2015;35(05):487-499. Doi: 10.1016/j.semnephrol.2015.08.010 
592 Systemic Lupus Erythematosus and pregnancy Naseri et al.

14 Chen S, Sun X, Wu B, Lian X. Pregnancy in women with systemic lupus erythematosus: a retrospective study of 83 pregnancies at a single centre. Int J Environ Res Public Health 2015;12(08): 9876-9888. Doi: 10.3390/ijerph120809876

15 Smyth A, Oliveira GH, Lahr BD, Bailey KR, Norby SM, Garovic VD. A systematic review and meta-analysis of pregnancy outcomes in patients with systemic lupus erythematosus and lupus nephritis. Clin J Am Soc Nephrol 2010;5(11):2060-2068. Doi: 10.2215/ CJN.00240110

16 Ritchie J, Smyth A, Tower C, Helbert M, Venning M, Garovic V. Maternal deaths in women with lupus nephritis: a review of published evidence. Lupus 2012;21(05):534-541. Doi: 10.1177/ 0961203311434939
17 Bramham K, Lightstone L. Pre-pregnancy counseling for women with chronic kidney disease. J Nephrol 2012;25(04):450-459. Doi: $10.5301 /$ jn.5000130

18 Clowse MEB, Wallace DJ, Weisman M, James A, Criscione-Schreiber LG, Pisetsky DS. Predictors of preterm birth in patients with mild systemic lupus erythematosus. Ann Rheum Dis 2013;72 (09):1536-1539. Doi: 10.1136/annrheumdis-2012-202449

19 Waltuck J, Buyon JP. Autoantibody-associated congenital heart block: outcome in mothers and children. Ann Intern Med 1994; 120(07):544-551

20 Costedoat-Chalumeau N, Amoura Z, Le Thi Hong D, et al. [Neonatal lupus syndrome: review of the literature]. Rev Med Interne 2003; 24(10):659-671. Doi: 10.1016/S0248-8663(03)00211-X 